\title{
UBE2C Gene
}

National Cancer Institute

\section{Source}

National Cancer Institute. UBE2C Gene. NCI Thesaurus. Code C92499.

This gene is involved in the regulation of protein ubiquitination. 